\title{
Variability in Forage yield of a Silage Maize "Zea mays, L."Base Population via Two Types of Families
}

\author{
M. Abd El-Sattar Ahmed ${ }^{1 *}$, M. H. El-Sheikh ${ }^{1}$, Kadria M.El-Sayed ${ }^{1}$ \\ and Doaa KH. Abd El-Mohsen ${ }^{2}$
}

1 Crop Science Dept., Fac.Agric.(El-Shatby),Alexandria Univ.,Egypt. (Mohamed.A@alexu.edu.eg)

2 Postgraduate student, Crop Science Dept., Fac.Agric.(El-Shatby),Alexandria Univ.,Egypt.

* corresponding anther .

\begin{abstract}
The base population for the recent study which is ayellow seed synthetic variety of maize was provided by Dr. M. Abd El-Sattar Ahmed, professor of crop science, Crop Science Department, faculty of Agriculture, Egypt.Two types of families had formulated, as a step before selection for high yielding ability. Those were half-sib (H.S) families and the first generation of self-pollination $\left(\mathrm{S}_{1}\right)$ families. Variability in the base population gene pool had estimated depending on variance components of the families. The ratio of $\sigma^{2}{ }_{\mathrm{A}} / \sigma_{\mathrm{G}}^{2}$ indicated that, additive genetic variance was more effective in controlling green and dry forage yield. This might indicate the importance of additive genetic variance in maize population, consequently, selection among inbred- progeny would expect to be superior to other methods under most genetic situations. Reduction in mean values of forage yield associated with selfing, reached 0.62 and 0.57 for green forage yield $(\mathrm{Kg} / \mathrm{plot})$ and dry forage yield $(\mathrm{Kg} / \mathrm{plot})$, respectively. Values of genotypic variances estimated from $S_{1}$ families were of larger magnitude amounted to 1.63 and 1.94 times the corresponding values for half- sib families in green forage yield and dry forage yield. Opposite to that, environmental variance estimates from $\mathrm{S}_{1}$ families were 0.56 and 0.55 of the respective values from half- sib families in green forage yield and dry forage yield respectively.Genotypic variations in term of coefficient relative to the overall mean of green yield and dry yield were less than $20 \%$ of the character mean when estimated from half-sib and $S_{1}$ families (10.85 vs. 13.96 and 10.21 vs. $14.31 \%$ for green and dry forage, respectively).Dry forage yield expressed the highest estimates of heritability in both family types ( 0.829 and 0.877 for half - sib and $S_{1}$ families, respectively). While, the obtained values for green forage yield were of lower magnitude ( 0.53 and 0.67 for half-sib and $\mathrm{S}_{1}$ families, respectively). This might indicate additional environmental influences with green forage yield.
\end{abstract}

Keywords: Genotypic variations, Half -sib, $S_{1}$ families, Green forage yield, Dry forage yield, Heritability.

\section{INTRODUCTION}

Worldwide, two thirds of the world production of maize is used as an animal feed, one quarter as human feed and less than $10 \%$ for industrial activities. Good silage maize hybrids are considered to have the same quality traits as grain maize hybrids. Silage maize hybrids are certified based on fresh and dry matter yield and the proportion of the ear. Many farmers still choose hybrids based on the grain yield, but this is not related to silage quality.

Estimating and comparing quantitative genetic information for different selection procedures would aid the identification of the best method for the improvement of desirable traits in maize populations. Genetic variability in small populations is affected by specific phenomena. The Joint effects of genetic drift and selection, in addition to the decrease in genetic variance due to the mere selection (Blumer effect), enhance the risk of losing alleles at selected or unselected genes and increase the inbreeding in the population by changing the family structure. Criteria for measuring this change in genetic variability are derived from the three approaches to describe the genetic variability. At the genealogical level, the kinship and inbreeding coefficients, or the effective population size, can be used. At the trial level, the estimation of its heritability is a good measure of remaining genetic variance. At the genome level, studying the polymorphism of known genetic markers can inform on the degree of genetic diversity. These criteria are to be integrated in specific tools for the study of genetic variability in small populations, the main criteria available to measure its change in populations is exposed and their relative efficiencies discussed (Rochambeau et. al, 2000).

Mikhiel (1987), evaluated a collection of 169 farmers seed-lots representing north delta governments of Egypt. The results showed that, dry forage yield significantly varied among the tested collections in the two regions of the study i.e., "Alexandria and Nubaria". Estimates of genetic as well as phenotypic variance were subject to location variations, where, lower estimates were recorded in Alexandria than Nubaria region. The genetic coefficients of variability for dry yield were 10.5 and $14.6 \%$ at Alexandria and Nubaria, respectively. Heritability estimates in narrow sense for dry forage yield of half-sib families of barseem, were relatively moderate reached about $44 \%$. Genetic coefficients of variability for dry yield were 10.5 and $14.6 \%$ at Alexandria and Nubaria, respectively. The author stated that, these figures prove the incidence of slight inherent genetic variability within the collection for forage yield, in both locations, he added that, selection based on total genetic variance, might be feasible in that Egyptian clover collection. Daros et.al. (2004), studied a number of problems needed to be solved to increase production, With the objective of developing superior genotypes in popcorn, Experiments were carried out 
in two Brazilian localities. The analysis of variance revealed environmental effects for all evaluated traits, In addition, the set as source of variation was significant for most traits i,e, grain yield, weight of grain in $\mathrm{kg} . \mathrm{ha}^{-1}$.Differences among genotypes were also detected ( $1 \% \mathrm{~F}$ - test), making viable the proposition of using the genetic variability in the popcorn population as a basis for future recurrent selection cycles. Sardaret.al. (2006) computed broad sense heritability estimates, genetic advance and relative expected genetic Advance (REGA) for different fodder yield related traits in two maize populations during Kharif 2002 and 2003.Two maize populations, DRS; developed through recurrent selection and DMS developed through mass selection, were grown in modified RCBD with two replications. They found that, mean squares from the analysis of variance among $\mathrm{S} 1$ families for both maize populations indicated highly significant $(p \leq 0.01)$ differences for all the studied traits. Estimates of genetic variances were significant for all traits except stem girth in both populations. Genetic variances in comparison to respective environmental variances were greater for majority of the traits in both populations. Heritability estimates were high and significant for all the traits in both populations. Genetic advance was higher for fresh fodder yield in the DRS population and for dry matter content in DMS population. REGA\% was higher for fresh fodder yield in DRS population while DMS population attained higher values for dry matter content. The higher heritability estimates, genetic advance and REGA for fresh fodder yield in DRS population indicates that recurrent selection method was comparatively more effective in improving maize population for fodder yield parameters. BaduApraku (2007), studied the genetic variances and correlations in early tropical white Maize population after three cycles of recurrent selection for Striga Resistance. Three hundred full-sib families within half- sib groups from cycle 3 of TZE-W pop DT STR were evaluated under artificial Strigainfestation. Estimates of additive genetic variance was positive and moderate- to- large for grain yield ( $\mathrm{Mg} / \mathrm{ha}$ ). The additive genetic variance was much larger than the dominance variance for all traits except striga emergence count. Narrow-sense heritability $\left(\mathrm{h}^{2}\right)$ estimate was $25 \%$ for grain yield and $0.90 \%$ for 13 other traits. The wide ranges, moderate- to- large additive genetic variance and expected gain/cycle of selection, and moderately low to high narrow sense heritability estimates observed in TZEE-W pop DT STR $\mathrm{C}_{3}$ indicate that sufficient residual genetic variability still exists in the population to allow further improvement for grain yield and most other traits in the population. Grain yield had a large positive additive genetic correlation with EPP, a large negative genetic correlation with striga damage ratings, and moderately large negative genetic correlations with flowering traits and striga emergence count at 10 WAP.Ajala et.al (2009),compared the predicted responses to three types of recurrent selection procedures for the im- provement of a maize (Zea mays, L.) population. They reported that, considerable genetic variability existed within the population FARZ23 (096EP6) for effective selection for each of the traits considered, using any of the procedures; namely full-sib, half- sib and $S_{1}$ family selection. Heritability estimates ranged from moderate tolarge for most traits. Direct selection for grain yield was expected to result in favorable increases in other traits.Turi et.al, (2007), assessed the magnitude of genetic variability in maize genotypes for yield and yield components under agro climatic conditions of Peshawar valley. Significant variability was observed for cob length, gain rows $\mathrm{cob}^{-1}$, fresh cob weight, grains moisture content, 300- grains weight and grain yield. They noticed a considerable amount of diversity among the tested populations which could be manipulated for further improvement in maize breeding. Ajala et.al (2010), In a study, maize population was subjected to both full-sib and $S_{1}$ recurrent selection schemes to determine the better of the two procedures for improving the population for tolerance to low soil nitrogen. For both schemes, estimated genetic variances were generally large enough for effective selection to take place. Except for ears per plant and stay green under low-N, genetic variances due to $S_{1}$ were larger than those due to fullsib selection. Also, genotype $\mathrm{x}$ environment component of variance due to $S_{1}$ selection was larger than those due to full-sib selection. Genetic variances under high-N for most traits were also larger for $S_{1}$ than for full-sib, but variances due to genotype $\mathrm{x}$ environment interaction under high-N were larger for full-sib selection for ear aspect, and grain yield. Heritability estimates for all the traits except for root lodging under low-N were moderate to high, but the estimates were higher for $S_{1}$ than for full-sib family selection under both selection types. However, considering time, cost and operational efficiency, modified fullsib family selection is considered more efficient to $S_{1}$ selection for the improvement of maize for tolerance to low soil nitrogen. Hallauer and Carena. (2012), stated that. Estimates of the genetic variation among progenies tested $\left(\sigma_{g}^{2}\right)$, interactions of progenies with environments $\left(\sigma_{g e}^{2}\right)$, and experimental error $\left(\sigma_{\mathrm{e}}^{2}\right)$ were obtained from the combined analyses of variance for each cycle of selection and then averaged across cycles for each selection program. From the estimates of the components of variance, estimates of heritability $\left(\mathrm{h}^{2}\right)$ on a progeny mean basis, the genetic coefficient of variation among progenies tested relative to their mean, $(\mathrm{GCV})$, selection differentials (D), predicted genetic gains $\left(\Delta_{\mathrm{G}}\right)$, and least significant differences (LSD) were calculated and averaged across cycles of selection. The average estimates of $\sigma_{g}^{2}$ were largest for inbred progeny selection and smallest for half-sib family selection as expected. Averaged expected genetic gain across all intrapopulation selection programs was $3.17 \mathrm{ha}^{-1} \mathrm{yr}^{-1} v$. $2.32 \mathrm{q} \mathrm{ha}^{-1} \mathrm{yr}^{-1}$ for inter-population reciprocal recurrent selection, or $2.64 \mathrm{q} \mathrm{ha}^{-1} \mathrm{yr}^{-1}$ across all method. On 
a per cycle and per year basis the differences among types of progeny were relatively small, ranging from (3.75q ha $\mathrm{yr}^{-1}, 1.78 \mathrm{q} \mathrm{ha}^{-1}$ cycle $^{-1}$ ) for half-sib family selection to $\left(9.62 \mathrm{q} \mathrm{ha}^{-1} \mathrm{yr}^{-1}, 3.21 \mathrm{q} \mathrm{ha}^{-1} \mathrm{yr}^{-1}\right)$ for $\mathrm{S}_{2}$ inbred progeny selection.

In forage maize (Barrire et al., 1987, 2004, 2005), the genetic progress was close to 0.17 $\mathrm{t} / \mathrm{ha} /$ year for hybrids registered in France between 1986. In the period before 1986, forage yield improvement was correlative to the genetic progress in grain and was nearly equal to $0.10 \mathrm{t} / \mathrm{ha} /$ year (Barriere et al., 1987).In the USA, Lauer et al. (2001) highlighted an annual rate of forage yield increase of 0.13-0.16 t/ha since 1930.The discrepancy between European and US results is likely due to different evolutions of hybrid germplasm in Europe and in the USA.No data are available showing such a drift in maize breeding program in Egypt. However, similar results could be considered because similar progresses in maize use,stalk stand ability and plant type were obtained during the last years. In the search for a forage ideotype in maize, the breeding effort to be placedbiomass yield

The main objectives of the present study were detecting variations in forage yield in the reference population through studying two types of families i.e.; half-sib and $S_{1}$-families.

\section{MATERIALS AND METHODS}

The present study had carried- out at the Agricultural Experiment Station, Alexandria university, Alexandria, through two successive summer seasons of 2009 and 2010. The base population under study which is a yellow seed synthetic variety of maize were provided by Dr. M. Abd ElSattar Ahmed, Professor of Crop Science, Crop Science Department, Faculty of Agriculture, Alexandria, Egypt(Ahmed et.al, 2010). In the summer season of 2009, seeds of base population were planted at a plant density of 26000 plant /faddan. Normal practices for maize production were applied as recommended for optimum maize production in the growing region.

In 2009 summer, season, 300 plants were visually selected before flowering, depending on good general performance. Those selected plants were marked by label named (OP) to indicate the collection of their open pollinated seeds. In the meantime, another 300 plants were selfed to produce $S_{1}$ seeds. The highest seed producing 100 plants were saved as half- sib families, $S_{1}-$ seeds had harvested from each plant, separately, to represent the initial genetic make-up.Progenies were developed for $S_{1}$ - family selection by selfing 300 plants in the same summer season of 2009. Those plants were marked by label named $S_{1} . S_{1}$ seeds were harvested from each selfed plants, separately,

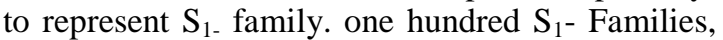
with enough selfed seeds, were saved.

In summer season of 2010, each hundred selected half-sib and $S_{1}$ - Families had evaluated in a trial of five sets, each of twenty families. Each set had treated as a randomized completed block experiment, with two replicates. The plot size was $2.8 \mathrm{~m}^{2}$ represented by one row, $4.00 \mathrm{~m}$ long and $0.7 \mathrm{~m}$. apart. Seeds planted in hills at 0.20 meter within ridge to obtained plant densityof 30000 plant / faddan.

The following characters had studied for each type of families.

\section{1- Green forage yield Per plot (kg)}

Determined as the total weight of harvested plants per plot $\left(2.8 \mathrm{~m}^{2}\right)$ in kilogram.

\section{2- Dry forage yield (kg)}

Estimated by multiplying green forage yield of each plot by the corresponding value of dry matter percentage.

\section{Statistical analysis:}

Analysis of variance for the data collected in each set as well as combined analysis over sets was performed as described by Cochran and Cox (1957). According to analysis of variance assumption, numerical data were subjected to square root transformation before analysis. Combined analysis over sets were performed when the assumption of homogeneity of error was not rejected. Forms of analysis of variance for each set and combined analysis over sets had illustrated in Table (1).

Table 1: Forms of analysis of variance for randomized complete block design in each set and combined over sets.

\begin{tabular}{|c|c|c|c|}
\hline Source of variation & d.f. & M.S. & E.M.S. \\
\hline $\begin{array}{l}\text { (a) Each set } \\
\text { Replications } \\
\text { Families } \\
\text { Error }\end{array}$ & $\begin{array}{l}(\mathrm{r}-1) \\
(\mathrm{f}-1) \\
(\mathrm{r}-1)(\mathrm{f}-1)\end{array}$ & $\begin{array}{l}\mathrm{M}_{1} \\
\mathrm{M}_{2}\end{array}$ & $\begin{array}{l}\sigma_{e}^{2}+r \sigma_{f}^{2} \\
\sigma_{e}^{2}\end{array}$ \\
\hline $\begin{array}{l}\text { (b) Over sets } \\
\text { Sets (S) } \\
\text { Rep/set } \\
\text { Families / sets } \\
\quad \text { Reps } \times \text { Families / sets (Eb) }\end{array}$ & $\begin{array}{l}(\mathrm{s}-1) \\
\mathrm{s}(\mathrm{r}-1) \\
\mathrm{s}(\mathrm{f}-1) \\
\mathrm{s}(\mathrm{r}-1)(\mathrm{f}-1)\end{array}$ & $\begin{array}{l}\mathrm{M}_{1} \\
\mathrm{M}_{2}\end{array}$ & $\begin{array}{l}\sigma_{e}^{2}+r \sigma_{f}^{2} \\
\sigma_{e}^{2}\end{array}$ \\
\hline
\end{tabular}


Were:

s: number of sets.

$\sigma_{\mathrm{e}}^{2}$ : error variance which represent environmental variation.

$\sigma_{\mathrm{f}}^{2}$ : Variance component among families and it is a function of the

genetic variance.

r: number of replications.

The variance components were calculated from the observed mean

squares as follows.

$\sigma_{\mathrm{f}}^{2}=\left(\mathrm{M}_{1}-\mathrm{M}_{2}\right) / \mathrm{r}$

$\sigma_{\mathrm{e}}^{2}=\mathrm{M}_{2}$

$\sigma_{p h}^{2}=\sigma^{2} \mathrm{f}+\sigma^{2} \mathrm{e}$

Genetic components of variations were estimated as follows;

Heritability $(\mathrm{H})=\sigma^{2} \mathrm{f} / \sigma^{2} \mathrm{ph}($ Hallauer and Miranda, 1981).

Were:

$\sigma_{\mathrm{f}}^{2}$ : the genetic variation among families.

$\sigma_{p h}^{2}$ : the phenotypic variation.

Predicted selection response was calculated using the formula adapted by Falconer(1989) as follows:

$\Delta \mathrm{G}_{\alpha}=\mathrm{K}_{\alpha} \cdot \mathrm{H} . \sigma_{\mathrm{ph}}$

Were;

$\mathrm{K}_{\alpha}$ : The selection differential for $\alpha$ selection intensity $\left(\mathrm{K}_{0.10}=1.76\right)$.

The percentage of predicted genetic advance under selection response $(\mathrm{G} \%)$ was calculated as; $\mathrm{G} \%=$ $\frac{\Delta G}{\bar{X}} \times 100$

Were ;

$\overline{\mathrm{X}}=$ Over all mean

The Coefficient of variability (C.V.) values for the phenotypic and genotypic variation were calculated as follows:

P.C.V $=\frac{\sqrt{\sigma_{p h}^{2}}}{\overline{\mathrm{X}}} \times 100$

G.C.V $=\frac{\sqrt{\sigma_{f}^{2}}}{\overline{\mathrm{X}}} \times 100 \quad$ (Burton and Devance,

Assuming that dominance variance $\left(\sigma_{D}^{2}\right)$ is less important than additive genetic variance $\left(\sigma_{\mathrm{A}}^{2}\right)$, the estimates of variance components, for the two types of families, would be used to calculate $\left(\sigma^{2}{ }_{\mathrm{A}}\right)$ and $\left(\sigma^{2}\right.$ D), as follows (Hallauer and Miranda, 1988):

$\sigma^{2} \mathrm{H} . \mathrm{S}=1 / 4 \sigma_{\mathrm{A}}^{2}$

$\sigma^{2} S_{1}=(1) \sigma_{A}^{2}+1 / 4 \sigma_{D}^{2}$
These two equations were used to drive additive and dominance variances as illustrated by Bernardo, 2002. The estimates of $\sigma_{\mathrm{A}}^{2}$ and $\sigma^{2}{ }_{\mathrm{D}}$ were used for estimating the expected genetic advance from selecting the superior $10 \%$ families in each selection program, when appropriate, as indicated by Fehr (1987).

\section{RESULTS AND DISCUSSION}

The base population for the recent study which is a synthetic variety of maize were provided by Dr. M. Abd El - Sattar Ahmed, professor of crop science department, faculty of Agriculture (El- Shatby)., Egypt. Two types of families had formulated, as a step before selection for silage characters and yield. Those were half-sib(H.S) families and the first generation of selfpollination $\left(\mathrm{S}_{1}\right)$ families. Variability in the base population gene pool had estimated depending on variance components of the aforementioned families. A selection index had derived for each family type depending on variance-covariance matrix of dry forage yield, total digestible nutrients(TDN), index of ensilability, Net Energy Lactation(N.E.L.) and milk yield per ton, weighed by the corresponding estimates of heritability. A selection intensity of $10 \%$ had practiced, resulting in twenty elite families in each selection scheme. Two synthetics had obtained. These were; a) $\mathrm{C}_{1}$ (H.S);cycle one of half-sib family selection and $b) C_{1}\left(S_{1}\right)$; cycle one of $\mathrm{S}_{1}$ family selection. The obtained results were presented for each part of the study separately i.e; variability in maize base population gene pool and response to selection for high forage yield.

Variability in the base population had determined through driving two types of families. These were, half-sib families (H.S), and first generation of selfing $\left(S_{1}\right)$ families. Those two types of families had evaluated in two different experiments. Portioning of variance components had used to estimate phenotypic, genotypic and environmental variances. The estimates of heritability and phenotypic variance had used to calculates the expected genetic advance from selecting the superior $10 \%$ families in each selection scheme, when appropriate.

Estimates of minimum, mean and maximum values for maize forage yield, derived from halfsib (H.S) and first selfing generation $\left(\mathrm{S}_{1}\right)$ had summarized in (Table 2). Reduction in mean values of forage yield associated with selfing, reached 0.62 and 0.57 for green forage yield $(\mathrm{Kg} / \mathrm{plot})$ and dry forage yield ( $\mathrm{Kg} / \mathrm{plot})$, respectively. Range values (difference between maximum and minimum values) for $S_{1}$ families were higher than the corresponding values for half-sib families in green forage yield and dry forage yield. These results were in accordance with those reported by Fehr(1987) and Ahmed (2006-a) 
Table 2: Estimates of minimum, mean and maximum values, for forage yield/plot (kg) of maize (2010 summer season).

\begin{tabular}{|c|c|c|c|c|c|c|}
\hline \multirow{2}{*}{ Characters } & \multicolumn{2}{|c|}{ Minimum } & \multicolumn{2}{c|}{ Mean } & \multicolumn{2}{c|}{ Maximum } \\
\cline { 2 - 7 } & H.S & $\mathbf{S}_{\mathbf{1}}$ & H.S & $\mathbf{S}_{\mathbf{1}}$ & H.S & $\mathbf{S}_{\mathbf{1}}$ \\
\hline Forage yield / plot & 15.260 & 13.310 & 18.178 & 18.066 & 22.380 & 22.825 \\
\hline Green forage yield & 5.722 & 4.869 & 6.820 & 6.781 & 8.153 & 8.724 \\
\hline Dry forage yield
\end{tabular}

H.S: half-sib families

$\mathrm{S}_{1}$ : First selfing generation families

The pertinent mean squares from analysis of variance over sets and estimates of family's variance component for both half-sib and first selfing generation $\left(S_{1}\right)$ families formulated in maize population regarding green forage yield and dry forage yield had summarized in (Table 3$)$. Significant $(\mathrm{P} \geq$ $0.01)$ differences among families/ sets had recorded for both family types in all studied forage yield. Mean squares among families were of larger magnitude for the first selfing generation $\left(\mathrm{S}_{1}\right)$ families relative to half-sib families. Meanwhile, within

families mean squares took an opposite trend for the studied characters.Family's variance component from $S_{1}$ families were 1.63, 1.94 times the corresponding values for half-sib (H.S) families for green forage yield $(\mathrm{Kg} / \mathrm{plot})$ and dry forage yield $(\mathrm{Kg} / \mathrm{plot})$ respectively. In general variance components for $S_{1}$ family exceeded the variance for half-sib family. These results were in accordance with those reported by Genter and Alexander (1962), Mota et al. (1975), Goulas and Lonnquist (1976) and Ahmed (2006b).

Table 3: pertinent mean squares from analysis of variance and estimates of family's variance components for half-sib (H.S) and first selfing generation (S1) families of forage yield/plot (kg) in maize (2010 summer season).

\begin{tabular}{|c|c|c|c|c|c|c|}
\hline \multirow{3}{*}{ Characters } & \multicolumn{4}{|c|}{ Mean squares } & \multirow{2}{*}{\multicolumn{2}{|c|}{$\sigma_{\mathrm{f}}^{2}$}} \\
\hline & \multicolumn{2}{|c|}{ Families /sets } & \multicolumn{2}{|c|}{ Error } & & \\
\hline & H.S & $\mathbf{S}_{1}$ & H.S & $\mathbf{S}_{1}$ & H.S & $\overline{S_{1}}$ \\
\hline \multicolumn{7}{|l|}{ Forage yield / plot } \\
\hline Green forage yield & $8.764^{* * *}$ & $13.282^{* * *}$ & 0.980 & 0.564 & 3.892 & 6.359 \\
\hline Dry forage yield & $1.151^{* * *}$ & $1.985^{* * i}$ & 0.181 & 0.101 & 0.485 & 0.942 \\
\hline
\end{tabular}

**: Significance at 0.01 level.

$\sigma_{\mathrm{f}}^{2}$ Family's variance component.

Variance components, i.e., genotypic $\left(\sigma_{\mathrm{g}}^{2}\right)$, environmental $\left(\sigma_{\mathrm{e}}^{2}\right)$ and phenotypic $\left(\sigma_{\mathrm{ph}}^{2}\right)$ and coefficient of variations at genotypic (G.C.V.) and phenotypic (P.C.V) levels for maize forage yield derived from half-sib (H.S) and first selfing generation families had illustrated in (Table 4). Values of genotypic variances estimated from $S_{1}$ families were of larger magnitude amounted to 1.63 and 1.94 times the corresponding values for half- sib families in green forage yield and dry forage yield. Opposite to that, environmental variance estimates from $S_{1}$ families were 0.56 and 0.55 of the respec-

tive values from half- sib families in green forage yield and dry forage yield respectively. The present results were in agreement with the publications of Hallauer and Miranda (1988), Fehr (1987), Falconer (1989) and Ahmed (2006.b).

Genotypic variations in term of coefficient relative to the overall mean of green yield and dry yield were less than $20 \%$ of the character mean when estimated from half-sib and $S_{1}$ families (10.85 vs. 13.96 and 10.21 vs 14.31 for green and dry forage, respectively). (Table 4).

Table (4):Estimates of variance components and coefficient of variation at genetic (G.C.V.) and phenotypic (P.C.V.) levels for forage yield/plot (kg) and forage botanical composition characters in maize (2010 summer season).

\begin{tabular}{|c|c|c|c|c|c|c|c|c|c|c|}
\hline \multirow{2}{*}{ Characters } & \multicolumn{2}{|c|}{$\sigma 2 \mathrm{~g}$} & \multicolumn{2}{|c|}{$\sigma 2 \mathrm{e}$} & \multicolumn{2}{|c|}{$\sigma 2 \mathrm{ph}$} & \multicolumn{2}{|c|}{ G.C.V. } & \multicolumn{2}{|c|}{ P.C.V. } \\
\hline & H.S & S1 & H.S & S1 & H.S & S1 & H.S & S1 & H.S & S1 \\
\hline \multicolumn{11}{|c|}{ Forage yield / plot $(\mathrm{kg})$} \\
\hline Green forage yield & 3.892 & 6.359 & 0.490 & 0.273 & 4.382 & 6.632 & 10.85 & 13.96 & 11.52 & 14.25 \\
\hline Dry forage yield & 0.485 & 0.942 & 0.090 & 0.050 & 0.575 & 0.992 & 10.21 & 14.31 & 11.12 & 14.69 \\
\hline
\end{tabular}

Phenotypic coefficient of variability clearly reflected the magnitude of differences in maize population forage yield. First selfed generation families expressed larger estimates in all studied characters (Table 9). Mikhiel (1987), evaluated a 
collection of 169 farmers seed-lots representing north delta governments of Egypt. The results showed that, dry forage yield significantly varied among the tested collections in the two regions of the study i.e.; "Alexandria and Nubaria". Estimates of genetic as well as phenotypic variance were subject to location variations, where, lower estimates were recorded in Alexandria than Nubaria region. The genetic coefficients of variability for dry yield were 10.5 and $14.6 \%$ at Alexandria and Nubaria, respectively. Heritability estimates in narrow sense for dry forage yield of half-sib families of barseem, were relatively moderate reached about $44 \%$. Genetic coefficients of variability for dry yield were 10.5 and $14.6 \%$ at Alexandria and Nubaria, respectively. The author stated that, these figures prove the incidence of slight inherent genetic variability within the collection for forage yield, in both locations, he added that, selection based on total genetic variance, might be feasible in that Egyptian clover collection. Tanner and Smith (1987), evaluated and compared eight cycles of half- sib [BSK(HI), and $\mathrm{S}_{1}$ progeny $\operatorname{BSK}\left(\mathrm{S}_{1}\right)$ ]recurrent selection for the changes in grain yield, grain moisture and lodging in BSK(HI)program. The results indicated that, genetic gains per cycle for grain yield in the populations per se for"zero" to" four" cycles , adjusted for the effects of finite population size, were significantly larger for $\mathrm{BSK}(\mathrm{S} 1)$ than for the BSK(HI).For "four" to" eight" cycles, genetic gains (adjusted for drift) in $\mathrm{BSK}(\mathrm{S} 1)$ were lower (not significantly) and higher for BSK(HI),, compared with their respective rates in "zero" to "four" cycles This resulted in significant differences between methods for "four" to "eight" cycles. Stojsin (1994), reported genetic changes associated with different methods of recurrent selection (modified ear- to row, selfed progeny selection, half sib progeny selection and reciprocal recurrent selection) in five maize populations (CGSyn. A, CGSyn. B, CGN and CGW). His study indicated that, none of the four methods of recurrent selection compared was the best under all circumstances. Selfed progeny selection achived the highest response to selection; however, this was offset by genetic drift. The half- sib procedures generally achived moderate response to selection

Table (5): Estimates of additive $\left(\sigma_{A}^{2}\right)$ and dominance $\left(\sigma_{D}^{2}\right)$ variance from the two types of families for forage yield/plot (kg) of maize (2010 summer season).

\begin{tabular}{|l|l|l|l|}
\hline Characters & $\sigma_{\mathrm{A}}^{2}$ & $\sigma_{\mathrm{D}}^{2}$ & $\sigma_{\mathrm{A}}^{2} / \sigma_{\mathrm{G}}^{2}$ \\
\hline Forage yield / plot & 15.568 & -36.836 & unity \\
\hline Green forage yield & 1.940 & -3.992 & unity \\
\hline Dry forage yield & \multicolumn{3}{|l|}{} \\
\hline
\end{tabular}

Heritability estimates for forage yield of maize population had presented in (Table 6). with minimal genetic drift. Comparison of advanced cycles of selfed progeny, half-sib progeny, and reciprocal recurrent selection as potential sources for improving CG28,CGKx86, and C0265 indicated that there were no significant differences among the three selection procedures. Hallauer and Carena. (2012), stated that. Estimates of the genetic variation among progenies tested $\left(\sigma_{g}^{2}\right)$, interactions of progenies with environments $\left(\sigma_{g e}^{2}\right)$, and experimental error $\left(\sigma_{e}^{2}\right)$ were obtained from the combined analyses of variance for each cycle of selection and then averaged across cycles for each selection program. From the estimates of the components of variance, estimates of heritability $\left(h^{2}\right)$ on a progeny mean basis, the genetic coefficient of variation among progenies tested relative to their mean, (GCV), selection differentials (D), predicted genetic gains $\left(\Delta_{\mathrm{G}}\right)$, and least significant differences (LSD) were calculated and averaged across cycles of selection. The average estimates of $\sigma_{g}^{2}$ were largest for inbred progeny selection and smallest for half-sib family selection as expected. Averaged expected genetic gain across all intra-population selection programs was $3.17 \mathrm{ha}^{-1} \mathrm{yr}^{-1}$ vs. $2.32 \mathrm{q} \mathrm{ha}^{-1}$ $\mathrm{yr}^{-1}$ for inter-population reciprocal recurrent selection, or $2.64 \mathrm{q} \mathrm{ha}^{-1} \mathrm{yr}^{-1}$ across all method. On a per cycle and per year basis the differences among types of progeny were relatively small, ranging from $\left(3.75 \mathrm{q} \mathrm{ha}^{-1} \mathrm{yr}^{-1}, 1.78 \mathrm{q} \mathrm{ha}^{-1}\right.$ cycle $\left.^{-1}\right)$ for halfsib family selection to $\left(9.62 \mathrm{q} \mathrm{ha}^{-1} \mathrm{yr}^{-1}, 3.21 \mathrm{q} \mathrm{ha}^{-1}\right.$ $\mathrm{yr}^{-1}$ ) for $\mathrm{S}_{2}$ inbred progeny selection.

Additive and dominance genetic variances were calculated for the base population of maize depending upon two types of evaluated families (half-sib and $\mathrm{S}_{1}$ ). The results had presented in (Table 5). Estimates of additive variance $\left(\sigma_{\mathrm{A}}^{2}\right)$ were positive for all studied forage yield character's. Meanwhile, the estimates of dominance variance $\left(\sigma^{2}\right)$ were negative for all character's. The ratio of $\sigma_{\mathrm{A}}^{2} / \sigma_{\mathrm{G}}^{2}$ indicated that, additive genetic variance was more effective in controlling green and dry forage yield. This might indicates the importance of additive genetic variance in maize population, consequently, selection among inbred- progeny would be expected to be superior to other methods under most genetic situations Weyhrich et.al (1998).

Commonly, estimates were of larger magnitude when estimated depending on first selfing generation $\left(\mathrm{S}_{1}\right)$ families compared to half-sib families for 
the studied characters. Green forage yield expressed the highest estimates of heritability in both family types $(0.888$ and 0.959 for half $-\mathrm{sib}$ and $\mathrm{S} 1$ families, respectively). While, the obtained values for green forage yield were of lower magnitude $\left(0.843\right.$ and 0.950 for half-sib and $S_{1}$ families, respectively). This might indicate additional environmental influences with forage drying.

Heritability estimate is largely depends on the nature of tested population, the environmental control and the estimation method. Martiniello and Lannucci (1998)published an estimate from evaluating half-sib families reached 0.25 to 0.29.Coors (1988), found that Broad-sense heritability estimates were 0.34 and $0.76 \mathrm{HS}$ and $\mathrm{S}_{1}$ families, respectively, for yield and 0.68 and 0.88 for moisture. The genetic covariance of HS and $\mathrm{S}_{1}$ progenies was compared to the variance among HS progenies for grain yield and moisture in order to estimate D1, the covariance of additive and homozygous dominance effects. A large negative value for D1 for yield was obtained.Pereira and Junior (2001), evaluated several agronomic traits such as grain yield (GY) and popping expansion (PE) in half-sib and full-sib families derived from an open pollinated popcorn population, low narrow sense of heritability for grain yield (GY) as opposed to popping expansion $\mathrm{PE}$; e) intermediate family heritability mean for grain yield (GY) and high for popping expansion PE; and f) high genetic gain estimates for both grain yield $(\mathrm{GY})$ and $\mathrm{PE}$ provided by the full-sib recurrent selection. Sardar et.al.(2006) computed broad sense heritability estimates, genetic advance and relative expected genetic Advance (REGA) for different fodder yield related traits in two maize populations during Kharif 2002 and 2003.Two maize populations, DRS; developed through recurrent selection and DMS developed through mass selection, were grown in modified RCBD with two replications. They found that, mean squares from the analysis of variance among S1 families for both maize populations indicated highly significant $(\mathrm{p} \leq 0.01)$ differences for all the studied traits. Estimates of genetic variances were significant for all traits except stem girth in both populations. Genetic variances in comparison to respective environmental variances were greater for majority of the traits in both populations. Heritability estimates were high and significant for all the traits in both populations. Comparison of two populations revealed that heritability estimates were higher for internode length and fresh fodder yield in the DRS population and for plant height, stem girth, flag leaf area and dry matter content in the DMS population. Genetic advance was higher for internode length, flag leaf area, fresh fodder yield in the DRS population and for plant height, stem girth and dry matter content in DMS popula- tion. REGA\% was higher for internode length and fresh fodder yield in DRS population while DMS population attained higher values for plant height, stem girth, flag leaf area and dry matter content. The higher heritability estimates, genetic advance and REGA for fresh fodder yield in DRS population indicates that recurrent selection method was comparatively more effective in improving maize population for fodder yield parameters. Ullah et.al, (2013), evaluated the performance of 196 half-sib families (HSF) derived from Sarhad white variety of maize at the research farm of Agricultural university, Peshawar using partially balanced lattice square design with two replications. Results indicated significant differences among HSF for all studied traits (i.e., flowering traits, plant height, ear height, grain moisture and 100-kernel weight), except, grain yield. Maximum heritability estimate $(69.17 \%)$ was observed for plant height, while, minimum $(5.08 \%)$ was observed for days to midsilking.

Expected genetic advance from selecting the superior $10 \%$ families (Table 6), were the highest for $S_{1}$ families relative to half-sib families for the studied characters. Expected gain from selection in units was the highest for green forage yield (5.772 and 4.347 from half- sib and $S_{1}$ family's selection, respectively). While the least expected gain from selection had expressed in dry forage yield $(1.125$ and 1.665 from half- sib and $S_{1}$ family's selection, respectively). Gain from selection in maize had expressed differently. The present results were in general agreement with finding of Hallauerand Miranda (1988) and Weyhrich et al. (1998). Hallauer and Carena. (2012), stated that. Estimates of the genetic variation among progenies tested $\left(\sigma_{g}^{2}\right)$, interactions of progenies with environment $\left(\sigma_{g e}^{2}\right)$, and experimental error $\left(\sigma_{\mathrm{e}}^{2}\right)$ were obtained from the combined analyses of variance for each cycle of selection and then averaged across cycles for each selection program. From the estimates of the components of variance, estimates of heritability $\left(h^{2}\right)$ on a progeny mean basis, the genetic coefficient of variation among progenies tested relative to their mean, (GCV), selection differentials (D), predicted genetic gains $\left(\Delta_{\mathrm{G}}\right)$, and least significant differences (LSD) were calculated and averaged across cycles of selection. The average estimates of $\sigma_{g}^{2}$ were largest for inbred progeny selection and smallest for half-sib family selection as expected. Averaged expected genetic gain across all intrapopulation selection programs was $3.17 \mathrm{ha}^{-1} \mathrm{yr}^{-1} \mathrm{vs}$ $2.32 \mathrm{q} \mathrm{ha}^{-1} \mathrm{yr}^{-1}$ for inter-population reciprocal recurrent selection, or $2.64 \mathrm{q} \mathrm{ha}^{-1} \mathrm{yr}^{-1}$ across all method. On a per cycle and per year basis the differences among types of progeny were relatively small, ranging from $\left(3.75 \mathrm{q} \mathrm{ha}^{-1} \mathrm{yr}^{-1}, 1.78 \mathrm{q} \mathrm{ha}^{-1}\right.$ cycle $\left.^{-1}\right)$ for half-sib family selection to $\left(9.62 \mathrm{q} \mathrm{ha}^{-1}\right.$ $\mathrm{yr}^{-1}, 3.21 \mathrm{q} \mathrm{ha}^{-1} \mathrm{yr}^{-1}$ ) for $\mathrm{S}_{2}$ inbred progeny selec- 
tion. Ordas et al, (2012), Compared two methods of reciprocal recurrent selection in maize (Zea mayz, L.). They found that the FS- $\mathrm{S}_{2}$ - RRS (fullsibs and $S_{2}$ families) method was successful for improving the yield of the population cross under optimum conditions ( the regression coefficient over cycles was $b=0.87^{* *} \mathrm{Mg} \mathrm{ha}^{-1}$ cycle $^{-1}$ ) without losing yield under high pressure of MCB (Mediterranean corn borer) attack $(b=0.07)$. On the contrary FS- RRS (full- sib RRS) failed to improve the yield of the population cross under optimum conditions $(b=0.65)$ and tended to decrease the yield under high levels of MCB attack $(b=0.26)$. We concluded that for developing high yielding and stable varieties, FS- $\mathrm{S}_{2}$ - RRS is more efficient than the classical FS- RRS method. EL-Gazzar, et. al. (2013), The additive gene effects were more important for silking data, plant height, ear height, grain yield. No. of ears/100-plant and ear diameter. While the non additive gene effects were important for ear length. Lujiang Li, et.al, (2013), carried out five cycles of bi parental mass selection (MS) to improve the narrow-base maize population $\mathrm{P} 4 \mathrm{C} 0$. It was found that MS was effective in improving the main traits and general combing ability (GCA), and it was effective on maintaining the genetic diversity of population. Ochieng (2013), studied the genetic effects from long term selection in populations of maize (Zea mays, L ). He found that, response to selection in NKF (Nebraska Krug Full-sib) for yield, ear height, plant height, and days to mid-anthesis was determined more by dominance than additive effects. However, nonbarren plants and percent prolificacy were appar- ently controlled by additive effects. Kapoor and Batra, (2015), evaluated twelve maize (Zea mays, L.) genotypes for character association. The genotypes were significantly different for all the characters, which indicated scope for further genetic studies. High heritability along with high genetic advance was recorded for plant height, leaf length leaf width, stem girth, number of leaves, crude protein, acid detergent fiber, dry matter yield and green fodder yield indicating the predominance of additive effects in the inheritance of these characters. The phenotypic coefficients of variation (PCV) estimates were invariably higher than their corresponding genotypic coefficient of variation (GCV) values thereby suggesting the environmental influence. High estimates of GCV and PCV were observed for plant height, leaf length, stem girth, number of cobs, number of seeds, dry matter yield, and green fodder yield suggesting that selection based on these characters would facilitate successful isolation of desirable types. Most of the yield contributing traits like plant height, leaf width, stem girth and dry matter yield as well as the quality trait neutral detergent fiber exhibited positive direct effect on green fodder yield. ElShamarka, et.al. (2015), made a diallel crosses, without reciprocals among eight new yellow maize inbred lines derived from different maize populations. The results indicated that mean squares due to crosses, G.C.A. and S.C.A. were highly significant for all studied traits indicating the importance of both additive and non- additive gene effects in the inheritance of these traits .

Table (6): Estimates of heritability $(H)$, genetic advance in absolute $\left(G_{A}\right)$ and percent of mean (GA\%) for green and dry forage yield/plot (kg) of maize (2010 summer season).

\begin{tabular}{|c||l|l||l|l||l|l|}
\hline \multirow{2}{*}{ Characters } & $\mathrm{H}$ & $\mathrm{G}_{\mathrm{A}}$ & $\mathrm{G}_{\mathrm{A}} \%$ \\
\cline { 2 - 7 } & $\mathrm{H} . \mathrm{S}$ & $\mathrm{S}_{1}$ & $\mathrm{H} . \mathrm{S}$ & $\mathrm{S}_{1}$ & $\mathrm{H} . \mathrm{S}$ & $\mathrm{S}_{1}$ \\
\hline Forage yield / plot & 0.888 & 0.959 & 3.272 & 4.347 & 18.00 & 24.06 \\
\hline Green forage yield & 0.843 & 0.950 & 1.125 & 1.665 & 16.50 & 24.55 \\
\hline Dry forage yield &
\end{tabular}

H.S: half-sib families

$\mathrm{S}_{1}$ : First selfing generation families

\section{Conclusions}

The obtained results might be summarized as follows:

- The ratio of $\sigma_{\mathrm{A}}^{2} / \sigma_{\mathrm{G}}^{2}$ indicated that, additive genetic variance was more effective in controlling green and dry forage yield. This might indicate the importance of additive genetic variance in maize population, consequently, selection among inbred- progeny would expected to be superior to other methods under most genetic situations.

- Reduction in mean values of forage yield associated with selfing, reached 0.62 and 0.57 for green forage yield $(\mathrm{Kg} / \mathrm{plot})$ and dry forage yield ( $\mathrm{Kg} / \mathrm{plot})$, respectively.
- Values of genotypic variances estimated from $S_{1}$ families were of larger magnitude amounted to 1.63 and 1.94 times the corresponding values for half- sib families in green forage yield and dry forage yield. Opposite to that, environmental variance estimates from $\mathrm{S}_{1}$ families were 0.56 and 0.55 of the respective values from half- sib families in green forage yield and dry forage yield respectively.

- Genotypic variations in term of coefficient relative to the overall mean of green yield and dry yield were less than $20 \%$ of the character mean when estimated from half-sib and $\mathrm{S}_{1}$ families (10.85 vs. 13.96 and 10.21 vs. $14.31 \%$ for green and dry forage, respectively). 
- Dry forage yield expressed the highest estimates of heritability in both family types $(0.829$ and 0.877 for half - sib and $S_{1}$ families, respectively). While, the obtained values for green forage yield were of lower magnitude $(0.53$ and 0.67 for half-sib and $S_{1}$ families, respectively). This might indicate additional environmental influences with green forage yield.

\section{REFERENCES}

Ahmed, M. Abd El-Satter. (2006 a).Variability, correlations and path-coefficient analysis in two populations of multi cut barseem clover. Alex. J. Agric. Res., 51(2): 63-72.

Ahmed, M. Abd El-Satter. (2006 b).Response to three methods of recurrent selection in a Khadarawi barseem (Trifolium alexandrium, L.) population. Alex. J. Agric. Res., 51(3): 13-23.

Ahmed, M.Abd EL-Sattar, M.H.EL-Sheikh , Kadria M El-Sayed and Doaa Khamis Abdel-mohsen .2010.Combining abilities of forage maize ensilability characters as affected by plant density .Proceeding 2nd Sci. Conf. Cereals Crops. February 10-11, 2010 (Alexandria), (1):51-61.

Ajala S.O., C.E. Ago and G. Olaoye, (2009). Comparison of predicted responses to three types of recurrent selection procedures for the improvement of a maize (Zea may, L.) population. Journal of plant breeding and crop science. 1(8): 284-292.

Ajala S.O., J. G. Kling, A. Menkir, and S. O. Alabi.(2010). Full- Sib vs. $\mathrm{S}_{1}$ selection scheme for the improvement of amaize population for tolerance to low soil nitrogen.Maydica 55: 239-248.

Badu-AprakuB.(2007). Genetic variances and correlations in an early tropical white maize population after three cycles of recurrent selection for striga resistance. Maydica 52: 205-217.

Barriere, Y., A.Gallais, M. Derieux and A. Panouille (1987). Etude de la value ragronomiqueenplanteentie 're au stade de re'colte ensilage de diffe'rentesvarie'te's de mai”s grain se'lectionne'es entre 1950 et 1980. Agronomie

Barriere, Y., D.Alber, O. Dolstra, C.Lapierre, M.Motto, A.Ordas, J. Van Waes, L. Vlasminkel, C.Welcker, and J.P. Monod, (2005). Past and prospects of forage maize breeding in Europe. I. The grass cell wall as a basis of genetic variation and future improvements in feeding value. Maydica 50:259-274.

Barriere, Y.,J.C. Emile, R.Traineau, F. Surault, M.Briand, and A. Gallais. (2004) Genetic variation for organic matter and cell wall digestibility in silage maize.Lessons from a 34-yearlong experiment with sheep in digestibility crates. Maydica 49:115-126.

Burton, G. W. and De Vance, E. H. (1953). Estimating heritability in tall Fescue (fescue orundinacea) from replicated clonal material. Agron. J., 45:478-481.

Cochran, W. G. and G. M. Cox.(1957). Experimental Designs.John Wiley \&sons.Inc. New York, USA.

Coors, J.G. (1988). Response to four cycles of combined half-sib and $S_{1}$ family selection in maize.Crop science 28(6)

Daros, M., A.T. JrAmaral, M. G. Pereira, F.S. Santos, A.P.C. Gabrial, C.A. Scapcm; S. de P. Freitas Jr and L. Silverio. (2004).Selection in inbred popcorn families. SCI. Agric (Piracicaba, Braz.), 61(6): 609-614.

EL- Gazzar, I.A.I.; M. A. EL- Ghonemy and S. Th. Mousa.(2013).Evaluation of new inbred lines of white maize via line $x$ tester analysis over three locations. J. plant production, Mansoura Univ. 4(6): 897-906.

El- Shamarka Sh. A, , M. A-Sattar Ahmed and M. M.el- Nahas. (2015). Heterosis and combining Ability for yield and its components through diallel cross analysis in maize (Zea mays L.). Alex. J. Agric. Res. 60 (2):87-94.

Falconer, D. S., (1989). Introduction to quantitative Genetics $3^{\text {rd }}$ Ed., Longman Scientific and Technical, New York, pages: 438.

Fehr, W.R. (1987).Principles of cultivar Development Vol. 1.Theory and technique MacMillianpub.Co, N.y, USA 536p.

Genter, C. F and M.W. Alexander (1962). Comparative performance of $\mathrm{S}_{1}$ progenies and testcrosses of corn. Crop Sci., 2:516-519.

Goulas, C. K and J. H. Lonnquist. (1976). Combined half-sib and $S_{1}$ family selection in maize composite population Crop. Sci., 16:461-464.

Hallauer, A. R. and J. B. Miranda (1988). Quantitative Genetics in maize breeding.Iowa State Univ. Press Ames. Iowa, USA.

Hallauer. A. R., M. J. Carena. (2012). Recurrnt selection methods to improve germplasm in maize. Maydica electronic publication 57: 266-283.

Kapoor R. and C. Batra.(2015). Genetic variability and association studies in maize (Zea mays L.).for green fodder yield and quality traits. Electronic Journal of plant breeding, 6(1): 233-240.

Lauer, J.G., J.G. Coors. and P.J.Flannery, (2001). Forage yield and quality of corn cultivars developed in different eras. Crop Sci. 41:1441-1455. 
Lujiang Li, W. Chen, K. Xiang, M. Reid, HaiLan, K. Yang, M. Zhang, G. Pan, T. Rong. (2013). The effect of five cycles of biparental mass selection on a narrow base maize population based on phenotype, combining ability, and SSR analyses. Maydica electronic publication,58: 238-242.

Martiniello, P. and A. Lannucci(1998). Analysis of seed yield components in four Mediterranean annual clovers. Field Crops Research, 55(3):235- 243.

Mikhiel, G. S. (1987). Studies on forage crops improvements Ph.D. Dissertation, Fac. Agric., Alex. Univ., Egypt.

Ochieng. J. A. W.,(1993). Genetic effects from long- term selection in population of maize (Zea mays, L.).Ph.D. Dissertation, Fac. Agric., Univ., Nebraska.

Ordas.B., A.Butron, A. Alvarez, P. Revilla and R.A Malvar, (2012).Comparison of two methods of reciprocal recurrent selection in maiz (Zea mays L.).Theor APPL Genet. 124:1183-1191.

Pereira M.G., and A. T. do A. Junior. (2001). Estimation of Genetic components in popcorn based on the nested design. Crop Breeding and Applied Biotechnology, 1(1): 3-10.

Rochambeau, H.D.; F.FHanoco and J.V.T. Khang (2000).Measuring and managing genetic variability in small population. Ann. Zootech, 49:77-93.
Sardar, A. H., R. S. Shah and G. Hassan, (2006). Estimates of variability, heritability and genetic advance for fodder traits in two maize populations. Pakistan Journal of Biological Sciences, 9: 2618-2623.

Stojsin, D. K.(1994). Genetic changes associated with different methods of recurrent selection in five maize population. Doctoral dissertation, University of Guleph, Canda.

Tanner, A. H. and O.S. Smith (1987). Comparison of half- sib and $S_{1}$ recurrent selection in the Krug Yellow Dent maize populations. Crop Sci. 27: 509-513.

Turi N. A., S. S. Shah, S. Ali, H. Rahman, T. Ali and M. Sajjad (2007). Genetic variability for yield parameters in maize (zea mays L.) genotypes. Journal of agricultural and biological science, 2: 4-5.

Ullah.K., H. UR Rahman, M. Noor, M. UR Rahman, M. Iqbal and S. Ullah. (2013). Heritability Estimates and yield performance of half-sib families derived from maize variety Sarhed white. Sarhad J. Agric. 29(1) 29-32.

Weyhrich R.A., K.R. Lamkey and A.R. Hallauer, (1998). Effective population size and response to $\mathrm{S}_{1}$ - progeny selection in the BS11 maize population. Crop Sci. 38: 11491158. 


\section{تقدير التصنيفات الوراثيه فى عشيرة اساس من الأره الشاميه باستخدام نوعيين من العائلات}

محمد عبد الستار احمد , محمد حسن الشيخ , قدرية محمود السيد , دعاء خميس عبد المحسن قسم المحاصيل - كلية الزراعة (الثاطبي) جامعة الإسكندرية

عشيرة الأساس للدراسة الحالية عبارة عن صنف تركيبي من الذرة الثامية أنتجه الأستاذ الدكتور محمد

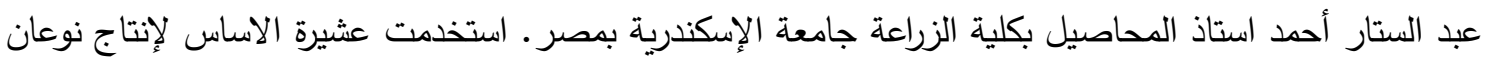
من العائلات كخطوة سابقة للانتحاب على اساس القدرة الإنتاجية. العائلات المنتجة مثلت كل من العائلات نصف لإنف لإنس الثقيقة وعائلات الجيل الأول للتلقيح الذاتي • وقد تم تقدير الاختلافات في الوعاء الجيني لعثيرة الاساس اعتماداً

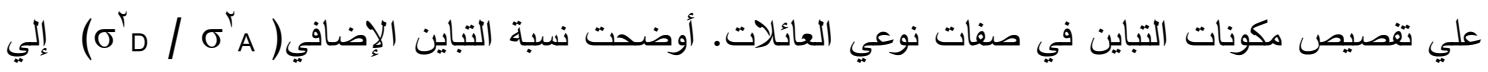

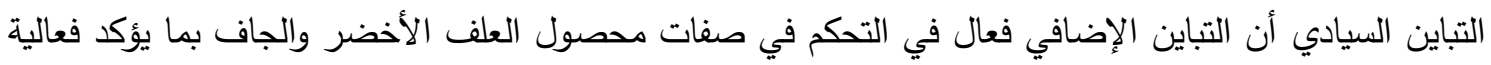
الانتخاب بين عائلات الجيل الأول للتلقيح الذاتي.لوحظ انخفاض في قيم الإين محصول العلف مصاحباً لجيل التلقيح الذاتي بلغ rاT, • و OV. V • لكل من محصول العلف الأخضر والجاف علي الترتيب.قيم التباين الوراثي المقدر بين

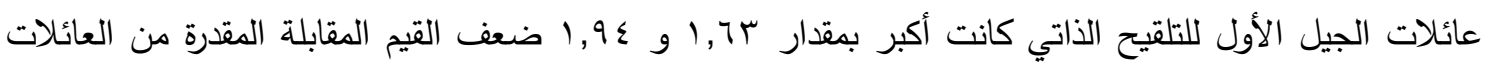
النصف المنسبة لصفات محصول العلف الأخضر والجاف مع وجود اتجاه معاكس في قيم التباين البيئي حيث بلغ

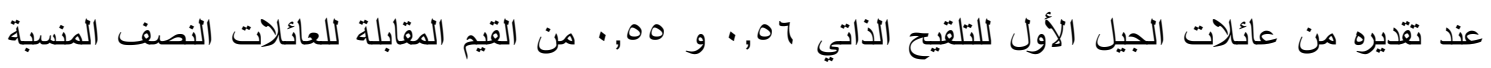
لصفتي محصول العلف الأخضر والجاف علي الترتيب.الاختلافات الوراثية المقدرة علي هيئة معامل منسوب

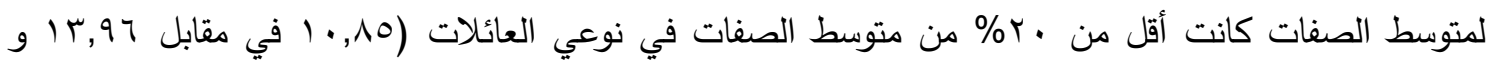

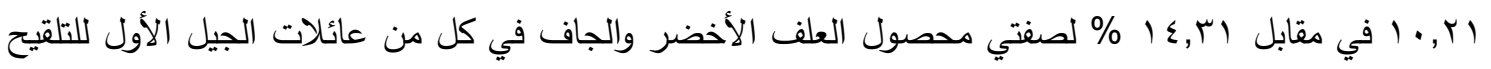
الذاتي والعائلات النصف المنسبة علي الترتيب). أعطي محصول العلف الجاف التقدير الأعلى لمعامل التوريث

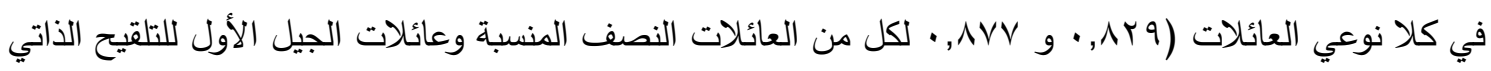

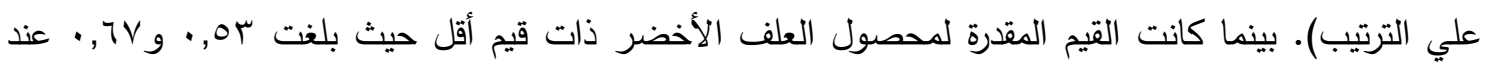
تقديرها من العائلات النصف المنسبة والعائلات ذاتية الاخصاب لجيل واحد علي الترتيب, مما يدل علي تأثر تلك الصفات بالظروف البيئية. 
Vol. 65, No. 2, pp. 139-149, 2020

Alex. J. Agric. Sci. 